\title{
GENETIC POLYMORPHISMS OF HUMAN COMPLE- MENT COMPONENTS BF AND C2 IN KOREAN: POPULATION AND ASSOCIATION STUDIES
}

\author{
Kyung Sook PARK, ${ }^{1}$ Katsushi Tokunaga, ${ }^{2}$ and Keiichi OMOTO ${ }^{2}$ \\ ${ }^{1}$ Department of Biology, Sung-Shin Women's University, Seoul 132, Korea \\ ${ }^{2}$ Department of Anthropology, Faculty of Science, University of \\ Tokyo, Tokyo 113, Japan
}

\begin{abstract}
Summary Polymorphisms of the factor B and the second component of human complement were investigated in 220 unrelated healthy Koreans. In the BF system, three phenotypes, S, FS, and F, were observed, while no rare variants were detected. The estimated allele frequencies for $B F^{*} S$ and $B F^{*} F$ were 0.775 and 0.225 respectively. In the $\mathrm{C} 2$ system, one common phenotype, $\mathrm{C}$, and three heterozygous types, $\mathrm{BC}, \mathrm{BHC}$, and $\mathrm{ATC}$, were observed. The estimated allele frequencies for $C 2^{*} C, C 2^{*} B, C 2^{*} B H$, and $C 2^{*} A T$ were $0.961,0.018,0.011$, and 0.009 , respectively. Significant positive association between $C 2^{*} A T$ and $B F^{*} F$ was found. Gene frequencies in Korean were compared with those in other populations.
\end{abstract}

\section{INTRODUCTION}

Factor B (BF) is one of the major participants in the alternative pathway of complement activation. The second component of human complement (C2) is an early component of the classical complement pathway. BF and $\mathrm{C} 2$ are single chain glycoproteins which take part in formation of the $\mathrm{C} 3$ and $\mathrm{C} 5$ convertases.

The genes for three components of the complement system, C2, C4, and $\mathrm{BF}$, have been localized between HLA-B and HLA-D in the major histocompatibility complex (MHC) of human chromosome 6 (Weitkamp and Lamm, 1982). Recently, these genes were mapped precisely using DNA walking analyses (Carroll et al., 1984).

Genetic polymorphism of human BF protein was discovered by Alper et al. (1972) using high voltage agarose gel electrophoresis followed by immunofixation. $\mathrm{BF}$ polymorphism has been investigated in many populations and shown to be controlled by codominant aileles at a single structural locus. Two common $(B F * S$ and $B F^{*} F$ ) and several uncommon variants have been identified and designated according to their relative electrophoretic mobilities (Mauff et al., 1978). These 
variants have been useful markers for association analyses with disease susceptibilities (for review, see Rittner and Bertrams, 1981), parentage testings, and population researches.

Genetic polymorphism of human $\mathrm{C} 2$ protein was first described by Hobart and Lachmann (1976), Alper (1976), and Meo et al. (1977) using isoelectric focusing followed by specific hemolytic overlay. C2 polymorphism is controlled by codominant alleles at a single structural locus. A common allele, $C 2^{*} C\left(=C 2^{*} l\right)$, a basic variant, $C 2^{*} B(=C 2 * 2)$, and two rare acidic variants, $C 2^{*} A l$ and $C 2^{*} A 2$, have been reported in Caucasoid populations (Pariser et al., 1978). In addition, an acidic variant, $C 2^{*} A T$, and two rare basic variants, $C 2 * B H$ and $C 2 * B J$, have been observed in Japanese (Tokunaga et al., 1981, 1982b, 1983).

The present paper demonstrates the results of population studies on BF and $\mathrm{C} 2$ polymorphisms and analyses on association between BF and C2 alleles in Korean. Also the gene frequencies estimated in Korean are compared with those reported in other populations.

\section{MATERIALS AND METHODS}

A total of 220 ACD-plasma samples were obtained from unrelated healty Koreans living in Seoul, Korea. The samples were stored at $-30^{\circ} \mathrm{C}$ for up to a few months before typing.

Phenotyping of $\mathrm{BF}$ was performed by immunofixation electrophoresis in agarose gel as described previously (Tokunaga et al., 1982a). Phenotyping of C2 was performed using isoelectric focusing in polyacrylamide gel and a specific hemolytic detection as described previously (Tokunaga et al., 1980), except that the thickness of the focusing gel was $0.5 \mathrm{~mm}$.

Association between $\mathrm{BF}$ and $\mathrm{C} 2$ alleles was analyzed in $2 \times 2$ contingency tables by Fischer's exact test.

\section{RESULTS AND DISCUSSION}

The results of BF typing of 220 unrelated healthy Koreans are presented in Table 1. The allele frequencies estimated for $B F^{*} S$ and $B F^{*} F$ were 0.775 and 0.225 , respectively. The deviation of the observed numbers of phenotypes from those expected on the Hardy-Weinberg equilibrium was statistically non-significant $\left(\chi^{2}=2.234,1\right.$ d.f., $\left.0.20>p>0.10\right)$. Table 2 shows BF allele frequencies in various populations. Variant alleles have been found at considerably low frequencies in Mongoloid populations. No rare phenotypes were observed in the present study. On the other hand, two relatively uncommon alleles, $B F^{*} F 1$ and $B F^{*} S O 7(=S 1)$, are known in Caucasoid and Negroid populations.

The frequencies of $B F^{*} S$ and $B F^{*} F$ in Koreans are similar to those reported in other Eastern Asians and Europeans, but differed markedly from those in Negroids. 
Table 1. Distribution of BF phenotype and allele frequencies in Korean.

\begin{tabular}{crrrr}
\hline Phenotype & Obs. No. & $(\%)$ & Exp. No. & Allele frequency \\
\hline S & 136 & $(61.8)$ & 132.1 & \\
FS & 69 & $(31.4)$ & 76.7 & $B F^{*} S: 0.775 \pm 0.020$ \\
F & 15 & $(6.8)$ & 11.1 & $B F^{*} F: 0.225 \pm 0.020$ \\
\hline Total & 220 & $(100.0)$ & 219.9 & 1.000 \\
\hline
\end{tabular}

$\chi^{2}=2.23,1$ d.f., $0.2>p>0.1$.

Table 2. Distribution of $\mathrm{BF}$ allele frequencies in various populations.

\begin{tabular}{|c|c|c|c|c|c|c|c|}
\hline \multirow{2}{*}{ Population } & \multirow{2}{*}{ No. } & \multicolumn{5}{|c|}{ BF allele } & \multirow{2}{*}{ Authors } \\
\hline & & S & $\mathrm{F}$ & $\mathrm{F} 1$ & $\mathrm{SO} 7$ & Others & \\
\hline Korea & 220 & .775 & .225 & 0 & 0 & 0 & Present study \\
\hline Japan & 360 & .824 & .176 & 0 & 0 & 0 & Horai, 1976 \\
\hline Japan & 487 & .801 & .198 & 0 & 0 & .001 & Tokunaga et al., 1982a \\
\hline China & 200 & .870 & .127 & 0 & .003 & 0 & Tongmao, 1983 \\
\hline Thailand & 184 & .902 & .098 & 0 & 0 & 0 & Greiner et al., 1980 \\
\hline India & $63-334$ & $.665-.738$ & $.246-.334$ & $0-.008$ & $0-.018$ & 0 & Papiha et al., 1982 \\
\hline Afghanistan & $118-298$ & $.696-.767$ & $.157-.268$ & 0 & $.023-.076$ & 0 & Benkmann et al., 1980 \\
\hline Saudi Arabia & 246 & .474 & .447 & .020 & .059 & 0 & Goedde et al., 1979a \\
\hline $\begin{array}{l}\text { South Africa } \\
\text { (Negroid) }\end{array}$ & 944 & .282 & .655 & .034 & .025 & 004 & Mauff et al., 1976 \\
\hline Cameroon & 275 & .373 & .595 & .029 & .003 & 0 & Goedde et al., $1979 \mathrm{~b}$ \\
\hline Tunisia & 375 & .617 & .281 & .019 & .083 & 0 & Davrinche et al., 1981 \\
\hline Portugal & 456 & .654 & .278 & .043 & .026 & 0 & $\begin{array}{l}\text { Weissmann and } \\
\text { Reuter, } 1981\end{array}$ \\
\hline Spain & 330 & .658 & .266 & .052 & 022 & 0 & $\begin{array}{l}\text { Rodriguez-Còrdoba } \\
\quad \text { et al., } 1981\end{array}$ \\
\hline $\begin{array}{l}\text { France } \\
\text { (Basque) }\end{array}$ & 201 & .550 & .296 & .139 & .015 & 0 & Ohayon et al., 1980 \\
\hline Italy & $161-431$ & $.705-.768$ & $205-.236$ & $.014-.022$ & $.013-.037$ & 0 & Scherz et al., 1982 \\
\hline Swiss & 654 & .805 & .176 & .010 & .009 & 0 & Scherz et al., 1977 \\
\hline West Germany & 1,245 & .808 & .174 & .008 & .009 & .001 & Mauff et al., 1975 \\
\hline Norway & 300 & .817 & .172 & .005 & .007 & 0 & $\begin{array}{l}\text { Teisberg and } \\
\text { Olaisen, } 1977\end{array}$ \\
\hline Norway (Lapp) & 197 & .888 & .112 & 0 & 0 & 0 & $\begin{array}{l}\text { Teisberg and } \\
\text { Olaisen, } 1977\end{array}$ \\
\hline
\end{tabular}

These racial differences in $\mathrm{BF}$ allele frequencies ensure that BF is a useful marker in the field of population genetics.

The C2 phenotypes observed in the present study are demonstrated in Fig. 1. 


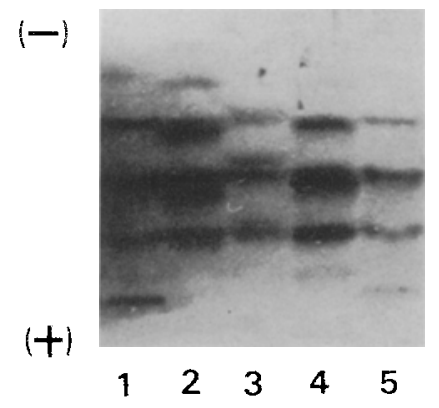

Fig. 1. Photograph of hemolytic overlay after isoelectric focusing showing four $\mathrm{C} 2$ phenotypes observed in Korean. 1 and 5, C; $2, \mathrm{BHC} ; 3, \mathrm{BC} ; 4, \mathrm{ATC}$.

Table 3. Distribution of $\mathrm{C} 2$ phenotype and allele frequencies in Korean.

\begin{tabular}{rrrrrr} 
Phenotype & Obs. No. & $(\%)$ & Exp. No. & \multicolumn{1}{c}{ Allele frequency } \\
\hline C & 203 & $(92.3)$ & 203.3 & $C 2^{*} C: 0.961 \pm 0.009$ \\
BC & 8 & $(3.6)$ & 7.7 & $C 2^{*} B: 0.018 \pm 0.006$ \\
BHC & 5 & $(2.3)$ & 4.8 & $C 2^{*} B H: 0.011 \pm 0.005$ \\
ATC & 4 & $(1.8)$ & 3.8 & $C 2^{*} A T: 0.009 \pm 0.005$ \\
Others & 0 & $(0.0)$ & 0.3 & & 0.999 \\
\hline Total & 220 & $(100.0)$ & 219.9 & & \\
\hline
\end{tabular}

Table 4. Distribution of C2 allele frequencies in various populations.

\begin{tabular}{|c|c|c|c|c|c|}
\hline \multirow{2}{*}{ Population } & \multirow{2}{*}{ No. } & \multicolumn{3}{|c|}{ C2 allele } & \multirow{2}{*}{ Authors } \\
\hline & & $\mathrm{C}$ & $\mathrm{B}$ & Others & \\
\hline Korea & 220 & .961 & .018 & BH: .011 AT: .009 & Present study \\
\hline Japan & 521 & .939 & .022 & BH: .006 AT: .034 & Tokunaga et al., 1981 \\
\hline Thailand & 184 & .951 & .049 & 0 & Greiner et al., 1980 \\
\hline Europe & 274 & .962 & .038 & 0 & Meo et al., 1977 \\
\hline Norway & 122 & .97 & .03 & 0 & Olaisen et al., 1978 \\
\hline West Germany & 289 & .965 & .035 & 0 & Dewald and Rittner, 1979 \\
\hline
\end{tabular}

Table 5. Relationship between BF and C2 phenotypes.

\begin{tabular}{rrrrrr} 
& & BF & & Total \\
C2 & & $F$ & FS & S & \\
\hline & ATC & 2 & 2 & 0 & 4 \\
& BHC & 1 & 3 & 1 & 5 \\
& BC & 0 & 3 & 5 & 8 \\
C C & 12 & 61 & 130 & 203 \\
\hline
\end{tabular}

Between $C 2$ AT positive and BF F positive: $p=0.020$.

Jpn. J. Human Genet. 
In addition to the common phenotype, $\mathrm{C}$, three heterozygous phenotypes were observed. These were identified as $\mathrm{BC}, \mathrm{BHC}$, and $\mathrm{ATC}$, respectively, by direct comparison with reference samples. The results of $\mathrm{C} 2$ typing of 220 unrelated healthy Koreans are presented in Table 3. The allele frequencies estimated for $C 2^{*} C, C 2^{*} B$, $C 2^{*} B H$, and $C 2^{*} A T$ were $0.961,0.018,0.011$, and 0.009 , respectively. The observed numbers of phenotypes were in good agreement with those expected under HardyWeinberg equilibrium.

Table 4 shows $\mathrm{C} 2$ allele frequencies in various populations. The frequencies of $C 2 * C(=C 2 * 1)$ and $C 2^{*} B\left(=C 2^{*} 2\right)$ in Korean are similar to those reported in other populations. However, two other variants observed in the present study, $C 2^{*} B H$ (formerly $A^{\prime}$, see Tokunaga and Omoto, 1982b) and $C 2^{*} A T$, have been found in no other populations except in Japanese (Tokunaga et al., 1981). This finding suggests the gene flow from Korea to Japan in the past.

Tokunaga et al. (1982a) reported the significant association of $C 2^{*} A T$ with $B F^{*} F$ and of $C 2^{*} B H$ with $B F^{*} F$. Interestingly, the association between $C 2^{*} A T$ and $B F^{*} F$ was also found in the present study (Table $5, \mathrm{p}=0.020$ by Fischer's exact test).

\section{REFERENCES}

Alper, C.A., Boenisch, T., and Watson, L. 1972. Genetic polymorphism in human glycine-rich beta-glycoprotein. J. Exp. Med. 135: 68-80.

Alper, C.A. 1976. Inherited structural polymorphism in human C2: Evidence for genetic linkage between $\mathrm{C} 2$ and Bf. J. Exp. Med. 144: 1111-1115.

Benkmann, H.G., Goedde, H.W., Agarwal, D.P., Flatz, G., Rahimi, A., Kaifie, S., and Delbrück, H. 1980. Properdin factor B polymorphism in Afghanistan. Hum. Hered. 30: 39-43.

Carroll, M.C., Campbell, R.D., Bentley, D.R., and Porter, R.R. 1984. A molecular map of the human major histocompatibility complex class III region linking complement genes $\mathrm{C} 4, \mathrm{C} 2$ and factor B. Nature 307: 237-241.

Davrinche, C., Rivat, C., Rivat-Peran, L., Helal, A.N., Boukef, K., Lefranc, M.P., and Lefranc, G. 1981. Genetic variants of human C3 and properdin factor B in a population from Tunisia. Hum. Hered. 31 : 299-303.

Dewald, G. and Rittner, C. 1979. Polymorphism of the second component of human complement (C2). Vox. Sang. 37: 47-54.

Goedde, H.W., Benkmann, H.G., Agarwal, D.P., Hirth, L., Bienzle, U., Dietrich, M., Hoppe, H.H., Orlowski, J., Kohne, E., and Kleihauer, E. 1979a. Genetic studies in Saudi-Arabia: Red cell enzyme, haemoglobin and serum protein polymorphism. Am. J. Phys. Anthrop. 50: 271-278.

Goedde, H.W., Benkmann, H.G., Agarwal, D.P., Bienzle, U., Guggenmoos, R., Rosenkaimer, F., Hoppe, H.H., and Brinkmann, B. 1979b. Genetic studies in Cameroon: Red cell enzyme and serum protein polymorphisms. Z. Morph. Anthrop. 70: 33-40.

Greiner, J., Weber, F.J., Mauff, G., and Baur, M. 1980. Genetic polymorphisms of properdin factor B (Bf), the second component (C2), and the fourth component (C4) of complement in leprosy patients and healty controls from Thailand. Immunobiology 158: 134-138.

Hobart, M.J. and Lachmann, P.J. 1976. Allotypes of complement components in man. Transplant Rev. 32: 26-42.

Horai, S. 1976. Genetic polymorphism of human serum factor B (Bf) in Japanese. Jpn. J. Human Genet. 21 : $177-186$.

Mauff, G., Hummel, K, and Pulverer, G. 1975. Properdin factor B (glycine-rich beta-glycoprotein 
or $\mathrm{C} 3$ proactivator)-polymorphism: Genetic and biochemical aspects. First application to paternity cases. Z. Immun-Forsch. 150: 327-338.

Mauff, G., Gauchel, F.D., and Hitzeroth, H.W. 1976. Polymorphism of properdin factor B in South African Negroid, Indian and Colored populations. Hum. Genet. 33: 319-322.

Mauff, G., Hauptmann, G., Hitzeroth, H.W., Gauchel, F., and Scherz, R. 1978. The nomenclature of properdin factor B allotypes. Z. Immun-Forsch. 154: 115-120.

Meo, T., Atkinson, J.P., Bernoco, M., Bernoco, D., and Ceppellini, R. 1977. Structural heterogeneity of $\mathrm{C} 2$ complement protein and its genetic variants in man: A new polymorphism of HLA region. Proc. Natl. Acad. Sci. U.S.A. 74: 1672-1675.

Ohayon, E., De Mouzon, A., Hauptmann, G., Klein, J., Abbal, M., Constans, J., Mayer, S., and Ducos, J. 1980. High frequency of the properdin factor Bf F1 and its linkage to HLA in French Basques. J. Immunogenet. 7: 441-445.

Olaisen, B., Teisberg, P., Gedde-Dahl, T., Jr., and Thorsby, E. 1978. Genetic polymorphism of the second component of human complement (C2). Hum. Genet. 42: 301-305.

Papiha, S.S., Noble, S.E., and Chahal, S.M.S. 1982. Properdin factor B (Bf) polymorphism in tribal populations of Himachal Pradesh, India. Hum. Hered. 32: 197-201.

Pariser, K.M., Raum, D., Berkman, E.M., Alper, C.A., and Agnello, V. 1978. Evidence for a silent or null gene in hereditary $\mathrm{C} 2$ deficiency. J. Immunol. 121: 2580-2581.

Rittner, C. and Bertrams, J. 1981. On the significance of C2, C4, and factor B polymorphisms in disease. Hum. Genet. 56: 235-247.

Rodriguez-Córdoba, S., Bootello, A., and Arnaiz-Villena, A. 1981. BF polymorphism and its relationship with HLA antigens in a sample of the Spanish population: High BF F1 frequencies. Tissue Antigens 17: 231-237.

Scherz, R., Pflugshaupt, R., and Bütler, R. 1977. Genetic polymorphism and glycine rich $\beta$-glycoprotein in the Swiss and Italian populations. Hum. Hered. $27:$ 143-146.

Scherz, R., Pflugshaupt, R., Bütler, R., and Peyretti, F. 1982. Genetic polymorphism of glycinerich beta-glycoprotein in the Italian population. Hum. Hered. 32: 11-14.

Teisberg, P. and Olaisen, B. 1977. Properdin factor B (Bf) polymorphism in Norway. Vox Sang. 32: $52-55$.

Tokunaga, K., Omoto, K., Araki, C., and Juji, T. 1980. Genetic polymorphism of the second component of human complement (C2) in Japanese. Jpn. J. Human. Genet. 25: 287-293.

Tokunaga, K., Araki, C., Juji, T., and Omoto, K. 1981. Genetic polymorphism of the complement $\mathrm{C} 2$ in Japanese. Hum. Genet. 58: 213-216.

Tokunaga, K., Araki, C., Juji, T., and Omoto, K. 1982a. Polymorphism of properdin factor B in Japanese. Description of a rare variant and data of association with HLA and C2. Hum. Genet. 60: $42-45$.

Tokunaga, K. and Omoto, K. 1982b. Isoelectric focusing pattern of desialyzed C2. Hum. Genet. 61: 375 .

Tokunaga, K., Omoto, K., Akiyama, N., Andoh, H., and Juji, T. 1983. A new C2 variant allele $C 2 * B J$. Ishoku (Transplantation) (in Japanese) 18: 177-179.

Tongmao, Z. 1983. Genetic polymorphisms of $\mathrm{C} 3$ and $\mathrm{Bf}$ in the Chinese population. Hum. Hered. 33: $36-38$.

Weissmann, J. and Reuter, W. 1981. Properdin factor B polymorphism in Portugal. Hum. Hered. 31: $370-372$.

Weitkamp. L.R. and Lamm, L.U. 1982. Report of the committee on the genetic constitution of chromosome 6. Cytogenet. Cell Genet. 32: 130-143. 